Collaborative geophysical monitoring of simulated forensic 'crime scenes' in the U.K.

Pringle, J.K. ${ }^{1}$, Cassella, J.P. ${ }^{2}$, Williams, A. ${ }^{3}$, Cross, P. $^{4}$, Ruffell, A. ${ }^{5}$ \& Masters, P. $^{3}$

${ }^{1}$ School of Physical Sciences \& Geography, Keele University, Keele, Staffs., ST5 5BG, UK.

${ }^{2}$ Dept. of Forensic \& Crime Science, Staffordshire University, Leek Road, Stoke-on-Trent, ST4 2DF, U.K.

${ }^{3}$ Cranfield Forensic Institute, Cranfield University, Shrivenham, SN6 8LA, U.K.

${ }^{4}$ School of Forensic \& Investigative Sciences, University of Central Lancashire, Preston, PR1 2HE, U.K.

${ }^{5}$ School of Geography, Archaeology \& Palaeoecology, Queens University, Belfast, BT7 1NN, U.K.

Email: j.k.pringle@keele.ac.uk

\title{
Summary
}

This paper provides an overview of current collaborative academic forensic geophysics research on various U.K. test sites to detail the importance of forensic simulated burial sites for forensic search investigators. Academic forensic test sites contain a variety of buried material objects that have been buried for various periods. The team also have access to historical burial grounds for data collection if required. Research is gaining an understanding of optimal search technique(s) for different buried targets, optimum methodologies and sequential search workflows. From this research, additionally a detailed understanding of the local depositional environment(s), particularly soil type(s), age/style of burial and local climate datasets are critical to have a successful detection. Ongoing long-term monitoring efforts are detailing optimal time windows for searches and techniques.

\section{Main Objectives}

1. Describe current forensic search best practice

2. Detail collaborative UK academic network

3. Describe forensic geophysics knowledge

4. Detail major forensic geophysics UK sites

5. Describe research findings

\section{New Aspects Covered}

Details UK academic forensic test sites and long-term studies to characterise detection technique(s), equipment configuration(s), data spacings/datasets to assist forensic search teams.

\section{Topics}

8. Near surface geophysics for forensic applications

2. Archeo-geophysics 




\section{Introduction}

The successful detection of a clandestine grave of a homicide victim brings closure to family members and gives the public confidence in criminal justice following a trial [1,2]. Accurate determination of the time since burial is also critical for forensic investigators to link suspects to or eliminating them from a crime [3]. Geoscientific methods are being increasingly utilised by forensic search teams for the detection and location of clandestinely buried material [4-5]. In the search for clandestine graves of murder victims, burials are usually shallow (less than 3 $\mathrm{m}$ and typically $0.5 \mathrm{~m}$ below ground level or bgl [6]), but current detection rates are low and, without locating the victim's body, obtaining a successful conviction can be very difficult $[1,2]$. Search investigators will use a variety of proved methods, which include scenariobased, feature focused, intelligence-led and systematic Standard Operating Procedures [1,2]. SOPs normally work through sequential workflows, from reviewing case information, sourcing background information and remote data analysis, before deciding upon search strategies, undergoing site reconnaissance and phased site investigations, and lastly intrusively investigating anomalous areas to give a success/failure exit strategy (see Fig. 1 and $[1,3])$.

Forensic site investigation methods vary depending upon the specific case, search site and numerous other factors that are reviewed elsewhere [4], but include, if appropriate, scenttrained cadaver dogs [7], forensic geomorphology [8], forensic botany [9] and entomology [10], near-surface geophysics [11-13], intrusive probing [14] and soil analysis [15-18] - see Table 1. Research using simulated clandestine grave burials provide critical information on optimal detection method(s), equipment configuration(s), sample point spacings, etc., especially if long-term monitoring are undertaken [6].

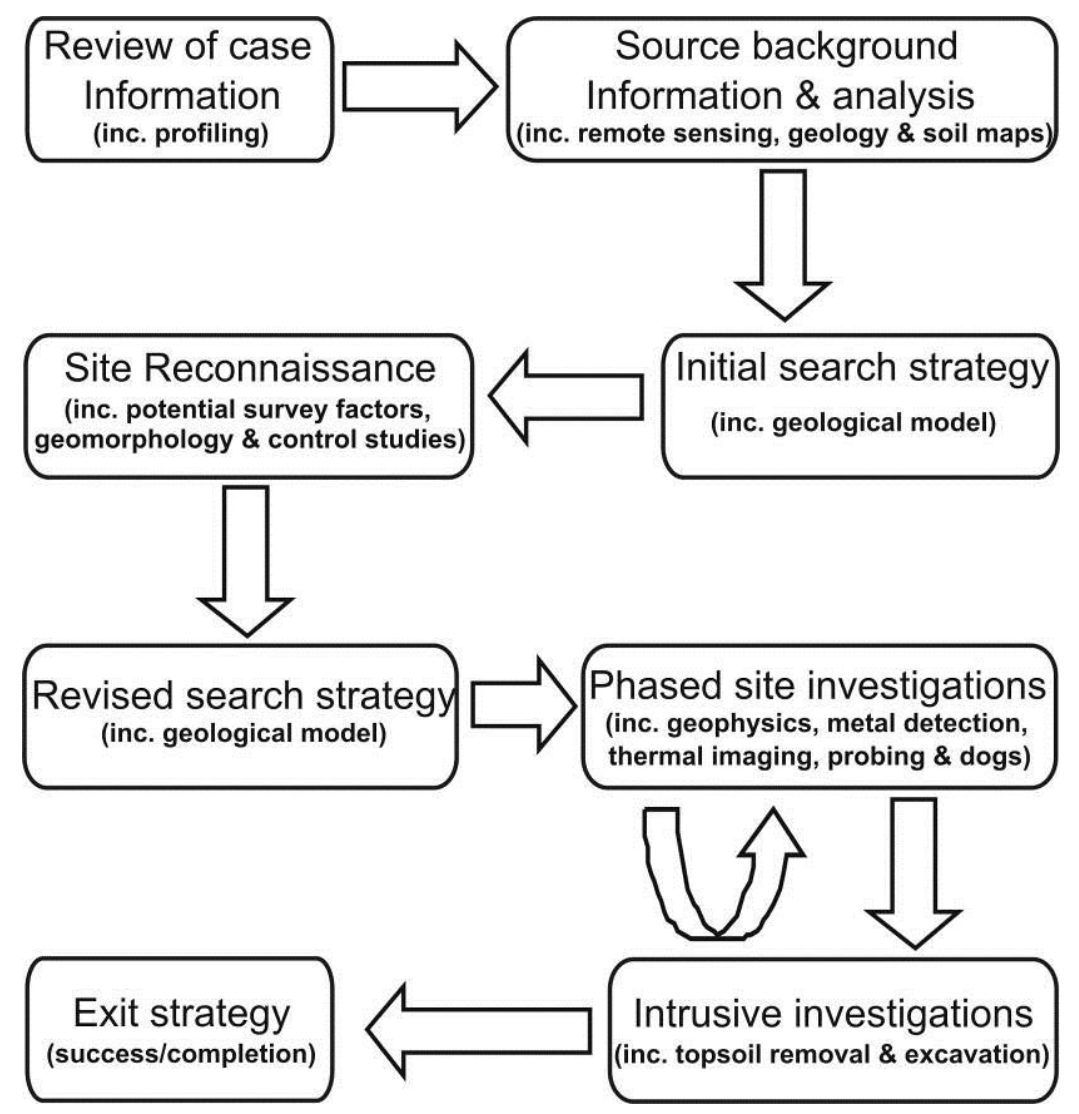

Fig. 1. Current optimised forensic search workflow. Adapted from [4].

Second International Conference on Engineering Geophysics 


\section{U.K. Academic Forensic Test sites}

Keele University has long-established forensic test sites in semi-urban/rural environments. The oldest burials (Dec. 2007) are simulated clandestine burials of murder victims, using three domestic pig carcasses as human analogues. One is wrapped and the other naked to provide the two typical burial scenarios. These have been repeatedly geophysically surveyed by fixed-offset electrical and Electrical Resistivity Imaging (ERI) surveys as well as multi-frequency (110-900 MHz) GPR datasets at least quarterly, and every month in the first three years post-burial. Studies have been published on determining what causes relative resistivity anomalies [19], magnetic surveys [20], measurements of decompositional fluid conductivities over time [3] as well as the 0-3 years post-burial datasets [6]. Repeat surveys suggest winter surveys are optimal and resistivity surveys should be undertaken six months to two years post-burial for optimal success. Conductivity of decompositional fluids could be potential grave location indicators and even date post-burial intervals. Both GPR and resistivity surveys should be undertaken if burial style is unknown. Keele also has access to local graveyard and cemetery sites and a Medieval monastery graveyard for research studies. A domestic patio scenario has also been created (Sept. 2010) with another pig carcass and a variety of buried munitions. Keele also has its own weather station linked into the U.K.'s Meteorological Office so corrections can be made for local temperature/rainfall variations.

Staffordshire University has forensic test sites in urban garden environments. Here studies have been undertaken for initial decompositional fluid research, magnetic survey trials [20] and optimal geophysical surveys for detecting clandestine burials [21], resistivity and GPR deemed optimal. Staffordshire are also leading inorganic chemical analysis of decompositional fluid collected by the research team, $\mathrm{Na} / \mathrm{K}$ major indicators and cadaverine/putrescene showing grave detection promise.

The University of Central Lancashire (UCLAN) have a forensic test site in an upland moorland environment, with the capability of handling large experiments that have been well published (e.g. [22]). They are also replicating the conductivity of decompositional fluid experiment [3].

Cranfield University has a forensic test site in a rural chalky environment. Their test site has been the subject of various decomposition studies and they are replicating the conductivity of decompositional fluid experiment [3]. They also have access to a woodland environment at Lincoln University that has been used for resistivity and magnetic survey studies [20], resistivity anomalies present even when surface remains are not obvious, thought to be decompositional fluids being retained in the local soil.

Queens University Belfast (QUB) have been leading the field in Water-Penetrating Radar (WPR) studies to detect submerged objects, with reviews [23] and research as well as best practice of search using geoscience methods [5] and historical cemetery research [24]. They are also very experienced in environmental forensic research. 
جامعة الإمارات العربيـة المتحدة (م) () ) United Arab Emirates University

\section{(n) \\ Emixate of Ylow Ohabi \\ Department of Munlclipal Affalrs}
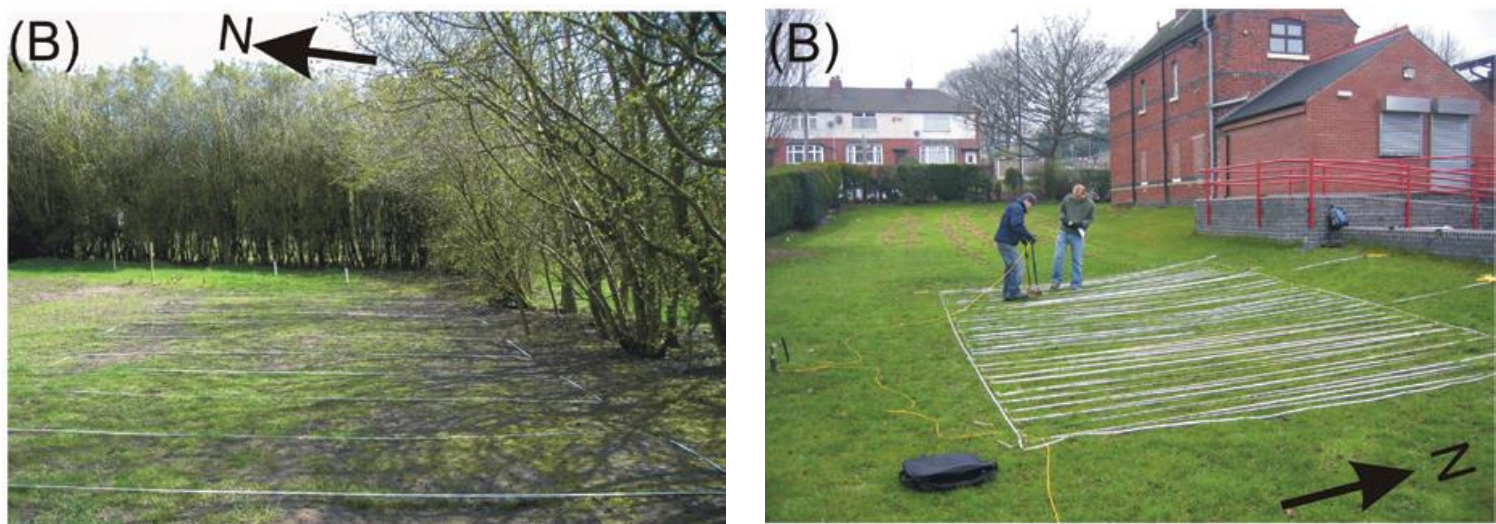

Keele University semi-rural test site

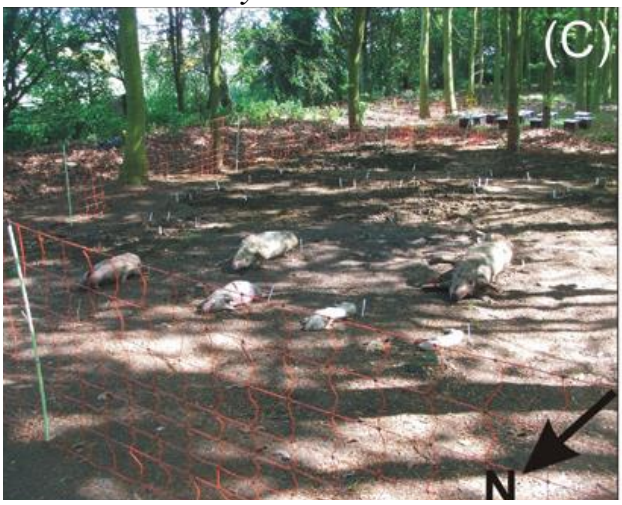

Staffordshire University urban test site

Cranfield's Lincoln woodland test site



UCLAN peat moorland test site

Fig. 2. Photographs of some of the available forensic test sites.

\begin{tabular}{|c|c|c|c|c|c|c|c|c|c|c|c|c|}
\hline \multirow{3}{*}{ Target(s) } & \multirow{2}{*}{\multicolumn{2}{|c|}{$\begin{array}{l}\text { Remote } \\
\text { sensing }\end{array}$}} & \multicolumn{10}{|c|}{ Site work } \\
\hline & & & \multirow{2}{*}{$\begin{array}{l}\text { Geomorph- } \\
\text { ologg/ } \\
\text { probing }\end{array}$} & \multirow{2}{*}{$\begin{array}{l}\text { Thermal } \\
\text { imaging } 1\end{array}$} & \multirow{2}{*}{$\begin{array}{l}\text { Special- } \\
\text { ist search } \\
\text { dogs }\end{array}$} & \multicolumn{3}{|c|}{ Near-Surfac } & \multicolumn{3}{|c|}{ Geophysics } & \multirow[b]{2}{*}{$\begin{array}{l}\text { Element } \\
\text { analysis }\end{array}$} \\
\hline & $\begin{array}{l}\text { Photo- } \\
\text { graphs }\end{array}$ & $\begin{array}{l}\text { Infra- } \\
\text { Red }\end{array}$ & & & & $\begin{array}{l}\text { Seis- } \\
\text { mology/ } \\
\text { Side-scan } \\
\text { sonar }\end{array}$ & $\begin{array}{c}\text { Cond- } \\
\text { uctivity }\end{array}$ & $\begin{array}{l}\text { Resist- } \\
\text { ivity }\end{array}$ & GPR & $\begin{array}{l}\text { Mag- } \\
\text { netics }\end{array}$ & $\begin{array}{c}\text { Metal } \\
\text { detector }\end{array}$ & \\
\hline $\begin{array}{l}\text { Unmarked } \\
\text { grave(s) }\end{array}$ & & (1) & & (1) & & (1) & (1) & & D & (1) & (1) & \\
\hline $\begin{array}{l}\text { Clandestine } \\
\text { grave(s) }\end{array}$ & & 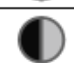 & & & & (1) & (1) & & D & & (1) & 1) \\
\hline $\mathrm{UXO} / \mathrm{s} / \mathrm{IEDs}$ &  & & & & & (1) & (1) & & D & & & $\sqrt{2}$ \\
\hline Weapons & D & & & (1) & $C$ & (1) & (1) & (1) & (1) & & & D \\
\hline $\begin{array}{l}\text { Drug/cash } \\
\text { dumps }\end{array}$ & (1) & C & & (1) & (1) & (1) & 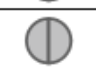 & ) & (1) & ) & & \\
\hline Illegal waste & & & & (1) & (1) & 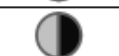 & & & D & (1) & & 1) \\
\hline \multicolumn{13}{|c|}{ Influence of search environment on chosen method(s) (above) effectiveness } \\
\hline Woods & & & & & & & ) & & D & & & ) \\
\hline Rural & & & & & & & & & & & & \\
\hline Urban & & & & & & 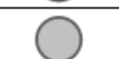 & & & 0 & O & & \\
\hline Coastal & & & & & & & & ) & P & & & ) \\
\hline Underwater & & & & & & & & & & & & \\
\hline & & & & & & & & & & & & \\
\hline
\end{tabular}

Table 1. Generalised search technique(s) for buried target(s) from good (black) to poor (white). Two end-member soil types shown. ${ }^{1}$ Time dependent. ${ }^{2}$ Water Penetrating Radar (WPR). Adapted from [4].

Second International Conference on Engineering Geophysics Al Ain, United Arab Emirates, 24-27 November 2013 


\section{Conclusions}

Clearly collaborative forensic geophysics is rapidly increasing to gain understanding of optimal search protocols and optimum detection types, but more research needs to be undertaken on varied objects in different environments and depositional settings to further increase forensic success rates.

\section{Acknowledgements}

The respective co-author Universities are thanked for support, and numerous undergraduate and postgraduate students research projects undertaken at these sites. Most co-authors are also members of the Forensic Geophysics Group, a specialist sub-group of the Geological Society of London, whose stated mission is to promote the study and understanding of forensic geoscience nationally and internationally, promoting good practise for academics and practitioners. 


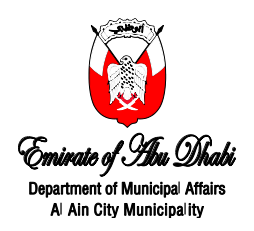

\section{References}

[1] M. Harrison and L.J. Donnelly, Locating concealed homicide victims: developing the role of geoforensics, in Criminal \& Environmental Soil Forensics (eds Ritz, K., Dawson, L. \& Miller, D.) pp. 197-219, Springer, The Netherlands, 2009.

[2] D.O. Larson, A.A. Vass and M. Wise, Advanced scientific methods and procedures in the forensic investigation of clandestine graves, J. Cont. Crim. Jus. Vol. 27, pp. 149-182, 2011.

[3] J.K. Pringle, J.P. Cassella and J.R. Jervis, Preliminary soilwater conductivity analysis to date clandestine burials of homicide victims, For. Sci. Int. vol. 198, pp. 126-133, 2010.

[4] Pringle J.K., A. Ruffell, J.R. Jervis, L. Donnelly, J. McKinley, et al. The use of geoscience methods for terrestrial forensic searches. Earth Sci. Rev. vol. 114, pp. 108-123, 2012.

[5] A. Ruffell and J. McKinley, Geoforensics. Wiley \& Sons, UK, 2008.

[6] J.K. Pringle, J.R. Jervis, J.D. Hansen, N.J. Cassidy, G.M. Jones, et al. Geophysical monitoring of simulated clandestine graves using electrical and GPR methods: 0-3 years, J. For. Sci. vol. 57, pp. 1467-1486, 2012.

[7] A Lasseter, K.P. Jacobi, R. Farley and L. Hensel, Cadaver dog and handler team capabilities in the recovery of buried human remains in the SE United States. J. For. Sci. vol. 48, pp. 1-5, 2003.

[8] Killam, E. W. The detection of human remains. (Thomas Publishers, USA, 2004).

[9] D.L. France, T.J. Griffin, J.G. Swanburg, J.W. Lindemann, G.C. Davenport, et al. A multidisciplinary approach to the detection of clandestine graves, J. For. Sci. 37, 1445-1458, 1992.

[10] J. Amendt, C.P. Campobasso, E Gaudry, C. Reiter, H.N. LeBlanc, et al. Best practice in forensic entomology: standards and guidelines, Int. J. Legal Med. vol. 121, pp. 90-104, 2007.

[11] D.C. Nobes, The search for "Yvonne": a case example of the delineation of a grave using nearsurface geophysical methods, J. For. Sci. vol. 45, pp. 715-21, 2000.

[12] J.K. Pringle and J.R Jervis, Electrical resistivity survey to search for a recent clandestine burial of a homicide victim, UK, For. Sci. Int. vol. 202, issue 1-3, e1-e7, 2010.

[13] A. Novo, H. Lorenzo, F. Ria and M. Solla, 3D GPR in forensics: finding a clandestine grave in a mountainous environment, For. Sci. Int. vol. 204, pp. 134-138, 2011.

[14] D.W. Owsley, Techniques for locating burials, with emphasis on the probe, J. For. Sci. vol. 40, pp. 735-740, 1995.

[15] A.A. Vass, R.R. Smith, C.V. Thompson, M.N. Burnett, N. Dulgerian, et al. Odor analysis of decomposing human remains, J. For. Sci. vol. 53, pp. 384-391, 2008.

[16] D.O. Carter, D. Yellowlees and M. Tibbett, Using ninhydrin to detect gravesoil, J. For. Sci. vol. 53, pp. 397-400, 2008.

[17] J. Dekeirsschieter, F.J. Verheggen, M. Gohy, F. Hubrecht, L. Bourguignon, et al. Cadaveric VOCs released by decaying pig carcasses in different biotopes, For Sci Int, vol. 189, pp. 46-53, 2009.

[18] M. Davla, M. Kalácska, T. R. Moore and A. Costopopoulos, Detecting graves with methane, Geoderma, vol 189-190, pp. 18-27, 2012.

[19] J.J. Jervis, J.K. Pringle and G.T. Tuckwell, Time-lapse resistivity surveys over simulated clandestine burials, For. Sci. Int., vol. 192, No. 1-3, pp. 7-13, 2009.

[20] A. Juerges, J.K. Pringle, J.R. Jervis and P Masters, P., Comparisons of magnetic surveys over simulated clandestine graves in contrasting burial environments. Near Surface Geophysics, vol. 8, pp. 529-539, 2010.

[21] J.K. Pringle, J. Jervis, J.P. Cassella and N.J. Cassidy, Time-lapse geophysical investigations over a simulated urban clandestine grave, J. For. Sci. vol. 53, No. 6, pp. 1405-1417, 2008.

[22] J. Bachmann and T. Simmons, The influence of preburial insect access on the decomposition rate, J. For. Sci., vol. 55, No. 4, 893-900.

[23] R. Parker, A. Ruffell, D. Hughes and J. Pringle, Geophysics and the search of freshwater bodies: a review, Science \& Justice, vol. 50, pp. 141-149, 2010.

[24] A. Ruffell, A. McCabe, C. Donnelly and B. Sloan, Location \& assessment of an historic (150-160 years old) mass grave using geographic \& GPR investigation, NW Ireland, J. For. Sci. vol. 54, pp. 382-394, 2009. 